This is the final peer-reviewed accepted manuscript of:

Munari F., Sobrero M., Toschi L. (2018) The university as a venture capitalist? Gap funding instruments for technology transfer, Special Issue "Instruments for Technology Transfer" on Technological Forecasting and Social Change, 127: 70-84

The final published version is available online at:

https://doi.org/10.1080/09537325.2016.1241874

Rights / License:

The terms and conditions for the reuse of this version of the manuscript are specified in the publishing policy. For all terms of use and more information see the publisher's website. 


\title{
The University as a Venture Capitalist? \\ Gap funding instruments for technology transfer
}

\begin{abstract}
The limited availability of private funding sources to support technology transfer activities represents a major barrier to the effective commercialization of university technologies. This article analyzes the key determinants of the activation of financial instruments by universities - such as seed funds and proof-of-concept programs - to address such funding gaps. Using data from a survey of technology transfer office managers in European universities, we detail the antecedents of the presence of such instruments at the university level and their perceived effectiveness. The findings, in turn, have notable policy implications.
\end{abstract}

Keywords: Funding gap; university seed funds; proof-of-concept programs; technology transfer

\section{Introduction}

National governments and regional authorities have increasingly focused on the development of technology transfer (TT) activities in order to facilitate the flow of ideas from universities into industry. Unfortunately, the lack of private funding sources to support such activities in their different forms - the so-called funding gap — constitutes a major barrier to the effective commercialization of university technologies (Audretsch et al., 2012; Benner and Sandstrom, 2000; Lockett and Wright, 2005; Munari et al., 2016). To address this challenge, various universities and public research organizations (PROs) have formally invested in the creation of internal financial mechanisms (i.e., "gap funding" instruments) in order to support translational research and fuel the growth of academic spin-offs, often in collaboration with public institutions (Darcy et al., 2009; Lerner, 2009; Wright et al., 2006). In recent years, two complementary instruments have received increasing attention in policy debates and academic literature, namely, proof-of-concept (POC) programs (Bradley et al., 2013; Gulbranson and Audretsch, 2008) and university seed funds (USFs) (Croce et al., 2014; Munari and Toschi, 2011). However, our understanding of the appropriate conditions for the activation of these instruments and their ultimate effectiveness remains limited. Indeed, much of the research on 
this topic has relied on case studies and anecdotes, often from largely successful research institutions. To address such gaps, the current study seeks to answer two key research questions:

1. What key factors in technology transfer offices (TTOs), the university, and the external context determine the activation of gap funding instruments by universities?

2. How effective are these instruments according to university TTO managers?

To investigate our research questions, we rely on empirical evidence from a survey of 128 university TTO managers across 32 European countries. With data from the survey, we first report a series of descriptive analyses of university-managed gap funding programs in Europe. Next, using a regression framework, we highlight that it is important to distinguish whether the efforts devoted to addressing the funding gap are a function of specific characteristics of the TTO or the university, or whether they are affected by the external ecosystem in which universities operate. In addition, we compare POCs and USFs in order to understand whether the conditions for activation and success vary according to the design of the scheme. To the best of our knowledge, this is the first study to provide a systematic analysis of the diffusion of university POCs and USFs across multiple countries and academic institutions. Understanding the factors that affect the creation of university gap funding measures may support university policies, organizational practices, and public policy choices, leading to a more favorable environment for the successful exploitation of results from research activities.

Our paper is organized in the following way. Sections 2 and 3 introduce the relevant literature and set out our multi-level conceptual framework. Section 4 describes the sample, the data and the methods used in the analyses. Section 5 presents the main empirical results. Section 6 concludes by discussing the policy implications of our findings for the design and implementation of effective gap funding programs in support of TT activities.

\section{Literature Review}

\subsection{Rationale and structure of "gap funding" instruments}


The commercialization of new inventions and technologies is a widespread additional component to the activities of modern universities and PROs, pursued with the aim of contributing to local economic and societal development (i.e., Horizon 2020 Agenda). However, several barriers and inefficiencies limit the transformation of new, research-based inventions into successful products or services. One of the most frequently cited hurdles is the "funding gap", that is, a lack of private funding sources to support TT activities in their different forms, regardless of the level of development of capital markets (Lockett and Wright, 2005; Mazzucato, 2013; Munari and Toschi, 2011). Such a gap is largely due to the "embryonic" nature of university-generated inventions, which tend to operate at the frontier of scientific advancements and thus involve considerable risks associated with their subsequent validation, industrialization, and commercialization. The time lag required to transform such discoveries into marketable products and the vast amount of resources needed to pursue the required development severely limit the opportunities to attract external funding. In the specific case of academic spin-offs, even in markets with a strong presence of dedicated financial operators, such as venture capital (VC), the general unavailability of private investments stems from high transaction costs, significant asymmetric information between science-based ventures and potential external investors, and high risks pertaining to the uncertainty of project outcomes (Mazzucato, 2013; Munari and Toschi, 2011; Murray, 2007; Murray et al., 1998). In addition, several countries face a more general underdevelopment of the $\mathrm{VC}$ infrastructure. For these reasons, private VC funding, which is typically focused on later-stage forms of financing, may not be available for academic start-ups at an early stage. The so-called 'valley of death' (Auerswald and Branscomb, 2003) thus emerges when government funding for research projects runs out but researchers and academic entrepreneurs have yet to secure external funding from private investors. Without the availability of funding instruments specifically dedicated to such a phase, research that may later be socially and economically useful, but is not yet commercially viable, can stall. 
Different support mechanisms seek to address these gaps, both as general policies and as specific institutional initiatives, including university accelerators and incubators, start-up competitions, and university-managed seed funds (Croce et al., 2014; Munari et al., 2015; Rasmussen and Sorheim, 2012). With this study, we focus on two types of instruments that are relatively more recent and are diffusing rapidly across universities all over the world: university-oriented POCs and USFs. These gap funding instruments differ significantly in their targets and are labeled in various ways, depending on the involved universities, investors, and countries. Thus, we group them into two major categories to facilitate their identification (see Figure 1):

--- Include Figure 1 around here ---

POC programs represent a recent, innovative mechanism increasingly embraced by public policies (e.g., Startup America Initiative, EU Horizon 2020 Framework, ERC Proof-of-Concept grants). These programs encompass several funding schemes that combine money, expertise, and training to help new inventions and discoveries emerge and to demonstrate their technical and commercial feasibility. Despite diverse labels across different universities and nations (e.g., POC funds, proof-ofprinciple funds, translational funding, pre-seed funding, verification funding, maturation programs, innovation grants, ignition grants), they all share common objectives and characteristics: to evaluate the technical feasibility and commercial potential of early-stage university/PRO ideas and technologies and to demonstrate their value to potential industrial partners and investors. Such programs provide capital and assistance to individual researchers or research teams across a wide spectrum of areas, such as intellectual property rights (IPR) protection, prototype building and technical verification, business plan development, market studies, entrepreneurial team formation, and networking with external partners. The ultimate goal is to advance the technology to a point at which it can be licensed to external industrial partners or a start-up can be created in order to attract 
the interest of investors in later stages of development. POC programs are typically administered in the form of grants, although different variants are available (e.g., repayment schemes, loans).

USFs, instead, are early-stage VC funds that have the deliberate and explicit mission of investing in university and PRO start-ups to support TT and the commercialization of university and public research endeavors. This general definition contains some features that define the nature of the USFs and differentiate them from other types of $\mathrm{VC}$ seed funds and from POC programs. Compared with other types of VC funds, USFs explicitly focus on investment in university and PRO start-ups because they are either activated and managed directly by the university/PRO, are partly funded by universities/PROs as limited partners, or involve formal partnerships or collaborations with universities/PROs. In contrast with POC programs, which fund individual researchers or projects in the pre-seed phase of development (i.e., before the company's legal foundation), USFs typically invest downstream in newly created start-ups. Their objective is to enhance the development of university/PRO start-ups to a point at which they are ready for investments by professional business angels or venture capitalists. They typically operate by providing equity capital to investee start-ups, although other forms (e.g., convertible loans) are also possible. Table 1 compares the two types of gap funding instruments by highlighting the differences in their objectives, focus of investment, investment typology, and investment stage.

--- Include Table 1 around here ---

\subsection{Diffusion of gap funding instruments in universities}

Despite their relative importance, very limited research addresses these emerging financial instruments for TT, and most available studies rely on single cases or anecdotal evidence (Bradley et al., 2013; Gulbranson and Audretsch, 2008; Maia and Claro, 2013; Rasmussen et al., 2011). With a few exceptions (Croce et al., 2014; Munari et al., 2015), multi-country comparisons are virtually absent in the literature, making it difficult to assess the diffusion of such instruments among 
universities in various national settings or the influence exerted by institutional and contextual factors. In addition, we suffer from a very limited understanding of the factors that determine the instruments' effectiveness in promoting TT.

Gulbranson and Audretsch (2008) compare two POC programs - the Deshpande Center at MIT and the von Liebig Center at UCSD — along several dimensions, such as initial funding, budget, number of employees, number of proposals funded, type of service provided (advisory, networking, education) and number of startups and licenses obtained. The aim of the paper is to provide insights into how these two centers have facilitated the transfer of university innovations into commercial applications and under which conditions these programs can prosper in order to determine possible key factors for the activation of similar exercises in other contexts. A clear message deriving from this work is that POCs are heterogeneous, as they offer a mix of approaches to provide customizable support and fill the funding gap.

Maia and Claro (2013) present a framework to assess the role of POC programs in a university ecosystem with a specific application to the case of the University of Coimbra, in Portugal. The aim of the work is to determine the main advantages associated with this type of instrument so that similar programs may be implemented in comparable university ecosystems. In particular, the POC plays a critical role for both the technology commercialization process, through networking outside academia, and the technology entrepreneurship education, by developing entrepreneurial skills for researchers. Also, in this case, strong attention is directed towards the external conditions surrounding the POC program.

Bradley et al. (2013) provide a descriptive analysis of 32 university-related POC centers (PoCCs) in the United States and indicate that they are associated with universities with more-established TTOs. However, these authors find no significant differences in the level of R\&D research conducted at universities with internal PoCCs and those without them. This exploratory account of the characteristics of PoCCs in the United States offers, as the authors themselves acknowledge, a starting point for considering more-detailed questions about the role and impact of POCs. 
The work by Rasmussen and Sorheim (2011) is the first to attempt to systemize the broad pool of financial programs set up by governments in six countries to bridge the funding gap. They identify three main categories of funding initiatives: (i) proof-of-concept schemes, whose main aim is to reduce the technological uncertainty of university projects; (ii) pre-seed schemes, with the goal of reducing organizational uncertainty and making the nascent venture more investor ready; and (iii) seed funding schemes for the provision of early-stage equity financing. While the first two schemes are more oriented towards the demand side of the financing gap, the latter is directed toward the improvement of the supply of funding.

Regarding USFs, Croce et al. (2014) use data from Thomson One to identify 25 USFs, 15 registered in Europe (mostly in the UK) and 10 in the United States. Their analyses suggest an older genesis of the USF phenomenon in the United States compared with Europe, as well as distinct investment policies. In particular, USFs in the United States tend to invest in more companies, using more rounds of investment and channeling more financial resources toward portfolio companies, compared with European USFs. Their investment strategies also tend to focus on technology sectors rather than life sciences. However, their study does not include an analysis of the influence of university- and context-level characteristics on the presence and impact of USFs.

\section{A multi-level framework of gap funding instruments}

University engagement in TT activities is a multilevel phenomenon (D’Este and Patel, 2007; Fini et al., 2011; Perkmann et al., 2013), and in order to provide a deep understanding of the mechanisms supporting their development, it is important to consider different factors at various levels of analysis (i.e., organizational and contextual) and simultaneously. We build on this insight to develop a multilevel framework to analyze universities' involvement in gap funding activities through POCs and USFs, such that we combine factors at the TTO, university, and environment levels. Figure 2 summarizes the framework and our main variables, which are described in more depth in the following section. 
--- Include Figure 2 around here ---

\subsection{TTO-level characteristics}

The spectrum of TT activities performed by universities and their ultimate performance depend significantly on their bridging units (the TTOs) in terms of organizational arrangements as well as the resources and capabilities they possess (Debackere and Veugelers, 2005; O'Shea et al., 2005; Schoen et al., 2014). Previous studies have identified three key factors at the TTO level for TT success. The number of people engaged at the TTO and their relative experience are important determinants of a successful transfer, because it requires time and effort to break through existing cultural barriers that separate the TTO, university scientists, and industry (Siegel et al., 2003). The age of the TTO also captures learning and experience effects in commercialization activities (Friedman and Silberman, 2003). Finally, according to Etzkowitz (2003), the level of autonomy of the TTO with respect to the university could enhance the activation of POC or USF initiatives by universities by providing the financial and administrative self-sufficiency required to run such types of programs.

\subsection{University-level characteristics}

A university's characteristics clearly impact the degree to which it engages in technology valorization activities (Di Gregorio and Shane, 2002; D'Este and Patel, 2007). A first logical candidate of such characteristics is university size. Larger universities can likely exploit larger financial endowments to fund their internal gap funding programs and benefit from greater visibility and prestige, such that they can attract external sponsors to fuel such initiatives (Bonaccorsi et al., 2014). Similarly, the age of the university might provide benefits in terms of visibility and learning advantages. Another important variable relates to the quality of research at the university level. Although the relationship between the quality of university research and the likelihood of engagement in TT activities remains 
uncertain (Perkmann et al., 2013), we posit that higher-quality research should facilitate the creation of a wider, stronger applicant pool and strengthen the selection process, ultimately enhancing the decision to activate internal financial programs in support of TT (Di Gregorio and Shane, 2003; Munari and Toschi, 2011; O'Shea et al., 2005; Owen-Smith and Powell, 2001). Another potential antecedent is the distinction between generalist universities, which cover a broad spectrum of disciplines (humanities, social sciences, science, technology, medicine), and specialized universities, which focus on specific scientific areas (Daraio et al., 2011). Within this latter group, technical universities (e.g., polytechnics, universities of applied sciences) and medical schools should have a greater likelihood of generating ideas and inventions with more potential for commercial exploitation. Therefore, they may have stronger incentives and needs to activate internal POCs and USFs to foster the commercial exploitation of their discoveries. In addition, universities differ in their public versus private status (Daraio et al., 2011). Private universities may be more likely than public universities to respond to the environment that surrounds the TT, such that they may have greater incentives to support the creation of internal gap funding measures.

\subsection{Environment-level characteristics}

The influence exerted by the regulatory, financial and innovation context could also matter in addressing the funding gap from both the supply and the demand side. Regarding the supply of funding, the amount of private third-party funding available in the region offers an important complement to universities' internal efforts in gap funding activities because it creates prime conditions for attracting subsequent investment rounds and exit opportunities (Bonaccorsi et al., 2014; Lockett and Wright, 2005). In terms of demand for universities' technologies, the regional levels of economic development and innovation intensity represent proxies for firms' willingness to sponsor the development of technologies generated by local universities (Azagra-Caro et al., 2006; Friedman and Silberman, 2003). Finally, the set of national legislations regulating the ultimate ownership of universities' intellectual property rights (IPRs) are also likely to affect the involvement 
of universities in the gap funding field. In the wake of the US experience with the Bayh-Dole Act, most European countries, with the exceptions of Sweden and Italy, moved away from their previous system based on inventor ownership (professor's privilege) and adopted a new system centered on institutional ownership, in which the university employing the inventor retained the ownership rights on patents generated by publicly funded research (Geuna and Rossi, 2011). Such a legislative regime should facilitate the establishment of gap funding programs at the university level due to the possibility for the academic institution to directly exploit its proprietary IPRs and benefit from the related commercialization returns.

\subsection{Effectiveness of gap funding instruments}

Once the determinants of POC and USF initiation have been identified, a second goal of our work is to empirically investigate the effectiveness of such gap funding instruments. A very limited number of empirical studies have systematically addressed this topic (Bradley et al., 2013; Croce et al., 2013; Munari et al., 2015), for two main reasons. First, seed funds and early-stage new ventures are difficult to evaluate given the limited availability of data (due to confidentiality issues) and the long-term horizon needed to assess impact (Cumming, 2007; Munari and Toschi, 2015). Second, the recent and still limited diffusion of gap funding instruments makes it difficult to access a large pool of comparable observations.

From a methodological point of view, different approaches can serve to assess the impact of such funding instruments (see Kochenkova et al., 2015): (1) a perceived assessment based on questionnaires submitted to recipient companies/projects (e.g., Giuri et al., 2013; Luukonnen et al., 2013); (2) a perceived assessment based on direct interviews with key stakeholders interested in the results of such initiatives, such as TTO managers, VC managers, entrepreneurs, or policy makers (e.g., Wright et al., 2006); or (3) quantitative analyses of the performance of recipient companies/projects, possibly by comparing their effectiveness with that registered by a matched- 
paired group of other companies and projects (e.g., Cumming, 2007; Croce et al., 2014; Munari and Toschi, 2011).

The only existing study to assess the performance of POC programs that adopts a quantitative approach is that by Bradley et al. (2013). These authors consider the potential economic impact of 39 university PoCCs established in the United States by calculating the number of start-ups generated by the respective universities before and after the founding of these centers. Their results show that the number of new university start-ups increased in the years after the founding of the PoCC, although, for several reasons, this interpretation is not straightforward. First, their analyses are explanatory, as the authors do not account for possible endogeneity issues or other influential covariates. Second, a simple count of spin-offs is an imperfect, narrow proxy for the real impact of such instruments. Third, they do not specify whether and how the PoCC actually supported the new university start-ups observed in the analyses. Croce et al. (2014) and Munari et al. (2015) present initial, unique evidence related to USFs, adopting the quantitative approach. Croce et al. (2014) describe the determinants of U.S. and European USF performance in terms of exit rates by portfolio companies (through initial public offering or acquisition) and find that performance is related to differences in terms of VC market characteristics and USF features (age and diversification). Munari et al. (2015) instead provide an overview of European USFs by comparing the performance (exit rates, staging, and syndication levels) of 733 USF-backed start-ups against the performance of 764 comparable start-ups backed by other VC funds (i.e., non-treated companies). The USF-backed companies perform better in staging and syndication but worse in terms of exit rates, probably due the embryonic and early-stage nature of the companies generated by these universities. Among the group of USF-backed companies, those financed by internally managed USFs and linked to universities with high scientific rankings attract more follow-up funding and investors. However, neither study accounts for the potential influence of more-specific characteristics of the universities and their internal TTOs. 
To complement this initial stream of the literature, in our empirical analyses, we provide an overall assessment of the performance of gap funding instruments activated by European universities, including both POCs and USFs, using the second approach. That is, we assess the perceived effectiveness of such programs in promoting TT activities, according to a survey of TTO managers from a sample of European universities, and we link it to the set of characteristics discussed above, at the TTO, university and context level.

\section{DATA AND METHODS}

\subsection{Sample}

We address our research questions using a two-step method to gather data. First, during 2013, we conducted an online survey of 589 TTO managers of European universities, based on an ad hoc questionnaire that included a specific section dedicated to gap funding programs. The questionnaire, which was developed within the research project FinKT (Financing Knowledge Transfer in Europe), was designed to provide a multicountry profile of the financial instruments that support TT activities and the obstacles to TT.

To improve the clarity of the instructions and to ensure completeness and appropriate usage of the language and terms, at the beginning of 2013 a pilot test based on a trial version of the questionnaire was conducted with a restricted group of TTO managers. They were selected experts from ASTPPROTON (Association of European Science and Technology Transfer Professionals), the panEuropean association for TT professionals involved in knowledge transfer between universities and industry. This pre-test received 8 responses, which we carefully analyzed. The final version of the questionnaire contained 41 items as well as two appendices that were to be completed only if the university/PRO had an internal POC program.

The questionnaire was first distributed to the 300 TTO professionals participating at the ASTPPROTON Annual Conference held in Vienna in May 2013. An email was sent immediately after the end of the ASTP-PROTON Annual Conference to all the participants, in order to solicit their 
participation in the online version of the questionnaire on the SurveyMonkey platform. In such occasion, we also e-mailed the questionnaire to an additional group of 363 TTO professionals identified through a dedicated web search of university TTOs for several European countries. This multi-step process thus allowed us to identify 663 TTO professionals from 589 universities across 32 European countries that we contacted with our online survey.

We completed three different rounds of reminders in order to solicit greater participation. Overall, we received responses from 135 universities in 28 European countries, although the final sample included 128 responses after we dropped some observations due to limited data availability. Of these respondents, 56 (44\% of the full sample) declared the presence of either an internal POC and/or an internal USF. Specifically, 51 respondents indicated the presence of an internal POC, and 30 noted the presence of an internal USF, of which 26 declared the joint presence of both a POC and a USF, and 4 respondents indicated the presence of only a USF. The information on these programs was collected in the appendices to the questionnaire. The questionnaire also gathered information about TTO characteristics such as age, number of personnel, and governance. We double-checked these responses in a second phase against information available on the web.

Also in the second phase, we collected complementary data from secondary sources, using the Eumida (European University Data Collection) database, to find university-level information. ${ }^{1}$ We relied on Eurostat to gather environment-related information (i.e., GDP per capita, innovation intensity, public funding, and VC funding) at regional and national levels. We referred to the NUTS2 geographic level of analysis to collect information on the regions in which the universities were located.

\subsection{Variables and econometric models}

\footnotetext{
${ }^{1}$ Eumida was a research project funded by the European Commission and undertaken during 2009-2011 to build a complete census of European universities. The pilot data collection focused in particular on active research universities.
} 
To assess the determinants of universities' engagement in gap funding activities, our first research objective, we adopted three dependent dummy variables that captured the likelihood that a university would activate internal gap funding programs. First, Internal Gap Funding Program takes a value of 1 if the university declared the presence of either a POC or USF program at the time of the FinKT survey, and 0 otherwise. Second, Internal POC Program equaled 1 if the university declared the presence of only a POC program. Third, Internal USF program equaled 1 in the case an internal USF only. We used a Probit specification for the regression analyses that use these binary variables to assess the probability of a university activating gap funding measures. Then, in a second set of regression analyses, we referred to survey data from university TTO managers to assess the respondents' perceptions of the effectiveness of their internal POC programs and USFs. One item asked the respondents to rate, on five-point Likert scales (with 1 "poorly effective" and 5 "extremely effective"), their perceptions of the effectiveness of such instruments as tools to enhance $\mathrm{TT}^{2}$. These responses were gathered only from those universities that previously indicated the presence of an internal gap funding program. ${ }^{3}$ In the perceived effectiveness regression models, we used ordered Probit regressions to account for the categorical and ordinal nature of the dependent variable, for which 1 is the lowest value and 5 the highest.

For all specifications of our models, we included three sets of explicative variables: (1) TTO characteristics, including age, size, and level of integration within the university; (2) university variables, including size, age, research quality, field specialization, and public vs. private nature; and (3) environmental variables, such as national legislation regulating academic inventions (professor

\footnotetext{
${ }^{2}$ The survey contained the two following questions on effectiveness, one for university seed funds and one for proof of concept funds: "How do you rate the overall effectiveness of the "seed funding" scheme implemented by the university in supporting the successful growth of academic spin-offs?" and "How do you rate the overall effectiveness of the POC program implemented by the university in supporting the successful commercialization of university technologies?"

${ }^{3}$ Unfortunately, only 58 of the 81 universities that declared the presence of gap funding programs answered the perceived effectiveness question. Therefore, our regression analyses are limited to this smaller sample. The FinKT questionnaire also asked respondents to nominate external gap funding programs (i.e., POCs or seed funds activated or managed not by the universities but by other actors, such as national or regional public authorities) whose formal mission was to support TT. We also asked the respondents to rate the perceived effectiveness of these external programs (also on five-point Likert scales) so we could compare the two types of measure, internal versus external.
} 
privilege versus institutional regime), local economic conditions of the regions in which the university is located (regional GDP per capita, regional public funding, regional high-tech focus, regional inventive activity), and availability of VC funding at the national level. In our regressions to assess the perceived effectiveness of the internal instruments, we also controlled for the distinction between internal USF and internal POC programs and between publicly versus privately backed programs. Table 2 describes each variable in detail and the sources we used.

--- Include Table 2 around here ---

\section{ANALYSES AND RESULTS}

\subsection{Descriptive statistics: the diffusion of university-related POCs and USFs}

In this section, we present a series of descriptive statistics to clarify the diffusion of university-related POC programs and USFs in our sample and the characteristics of the institutions that activated them. We also provide an initial characterization of these instruments according to a series of dimensions that are relevant for their design and management, such as the type of funding provided and the sources of their funds. Table 3 contains summary statistics as well as a breakdown in terms of the geographic distribution of universities across four major country groups: Western European, Eastern European, Northern European, and Southern European countries. ${ }^{4}$ As we find in Table 3, European universities feature many internal gap funding programs: $43 \%$ of the institutions in our sample reported the presence of an internal funding program (either POC or USF) to support the commercialization of university technologies. Approximately $40 \%$ of universities reported the presence of an internal POC program, whereas only $23 \%$ indicated an internal USF. A few universities implemented both instruments. The majority of universities with an internal USF (26 of

\footnotetext{
4 The groups of countries reflected the location of the respondents' university: Eastern Europe includes Bulgaria, Czech Republic, Estonia, Poland, Russia, and Slovenia; Western Europe includes Austria, Belgium, France, Germany, Hungary, Luxembourg, Netherlands, Slovakia, and Switzerland; Northern Europe includes Denmark, Finland, Iceland, Ireland, Lithuania, Norway, Sweden, and the United Kingdom; and Southern Europe includes Italy, Malta, Portugal, Spain, and Turkey.
} 
30) also managed an internal POC program. It is also worth highlighting that all the universities with both internal USF and POC programs were located in Belgium, Finland, Germany, Sweden, or the United Kingdom. This evidence suggests a second important finding, namely, the uneven distribution of university-related gap funding programs across European countries. The results in Table 3 suggest the important presence of such instruments in Northern European and Western European universities (in $73 \%$ and $52 \%$ of the universities in our sample, respectively) but a very limited presence in Southern European and Eastern European countries (5.7\% and 25\% of universities, respectively). Therefore, the funding gap instrument culture appears much better developed in Northern European countries, where university involvement in TT practices has a longer history and major public policies have been implemented over time to strengthen the TTO infrastructures at the university level ${ }^{5}$.

A further look at the characteristics of the TTOs and universities in our sample reinforces the existence of significant differences among European countries. On average, a university TTO in our sample employed approximately 11 people, had been in operations for around 11 years, and was usually structured as an internal unit of the university (in $85 \%$ of the cases). However, significant differences emerge across countries, such that TTOs from Eastern European countries were smaller (approximately 9 people) and younger (around 5 years) than TTOs from Northern and Western European countries (14 and 13 people and 13 and 13 years, respectively). The TTOs from Southern European countries fell in the middle. In terms of university characteristics, we note that, on average, the universities included in our sample had a total staff of approximately 2,900 people, although Eastern European universities were significantly smaller (approximately 1,900). The universities in our sample that also appeared in the Times Higher Education Ranking tended to concentrate in

\footnotetext{
${ }^{5}$ Our survey provides also additional interesting insights regarding the typical amount of money provided per commercialization project or start-up company by gap funding instruments. Unfortunately, only 43 respondents (out of 128) provided information on such variable in our survey, probably due to confidentiality issues. Therefore, we are not able to exploit such data in a more systematic way in our analyses. However, they can be informative to provide a more detailed picture of gap funding instruments. Our data based on this sub-sample of responses indicate that for POCs and USFs, the average level of funding provided per project equals approximately to 55,000 Euro and 543,000 Euro respectively (with median values equal to approximately 49,500 Euro for POCs and 180,000 Euro for USFs). The maximum amount provided for projects is instead equal (on average) to approximately 98,000 Euro for POCs and 1.1 Million Euros for USFs (with median values equal to approximately 75,000 Euro for POCs and 500,000 Euro for USFs).
} 
Northern and Western European countries but were substantially absent in Southern and Eastern European countries. Approximately one-quarter of our sample universities were technical/medical schools particularly concentrated in Eastern and Western European countries, in the latter case, largely due to Germany's influence.

Regarding the effectiveness of "gap funding" measures as perceived by TTO managers, our descriptive analyses show that the average assessment is largely positive (average value of 3.5 on a five-point scale), confirming their importance for undertaking the commercialization of university technologies. Across countries, our analyses indicate a relatively lower assessment by TTO managers from Southern and Eastern European universities (average perceived effectiveness $=2.333$ and 3.000, respectively) compared with Western and Northern European universities (average perceived effectiveness $=3.75$ and 3.46 , respectively).

The correlation matrix in Table 4 shows that the variables in our econometric models are not highly correlated. As an additional check, we calculated variance inflation factors (VIFs) for all our regressions. None of the scores approached the commonly accepted threshold of 10, and we can therefore rule out the existence of multi-collinearity problems (Freund and Wilson, 1998).

--- Include Tables 3 and 4 around here ---

In Table 5 (Panel A), we compare the mean values of TTO-, university-, and environment-level characteristics across universities with internal gap funding programs and those without such instruments. We also differentiate the former group into two subsamples: universities with only internal POC programs and universities with only internal USFs. We ran statistical tests to uncover any differences in the proportion or means for each variable in order to assess the significance levels of the reported differences. The TTOs of universities with an internal gap funding program tended to be significantly older than their counterparts (on average, 12.31 years vs. 10.15 years) and significantly larger in terms of internal personnel (on average, 15.31 employees vs. 7.56 employees). 
However, no statistically significant differences emerged regarding the TTO governance arrangements (integrated vs. autonomous). Therefore, a TTO of viable size and experience appears necessary to manage internal gap funding programs. In particular, USFs require more funding and higher commitment levels. Regarding university characteristics, we also note that universities with and without internal gap funding programs do not differ in size, nor do we find any major differences (at least at conventional statistical levels) in the degree of specialization (technical/medical vs. generalist universities) or public versus private status. A more sizeable difference instead emerges for university research quality. Universities in the former group have a significantly higher likelihood of being included in the top 200 world universities of the Times Higher Education Rankings compared with the latter group. Our data further suggest that when national legislation regulating patent ownership of academic inventions encourages inventor ownership (so-called professor privilege, as in Italy and Sweden) rather than institution ownership, universities tend to be less likely to activate gap funding programs (in only approximately $9 \%$ of cases, compared with $30 \%$ under the institutional regime). Furthermore, contexts with high GDP per capita, patenting activity and VC funding seem to create optimal conditions for gap funding programs. We found similar results in separate analyses of the two split samples of universities with POC or USF programs. Thus, our descriptive analyses indicate that a supportive institutional environment is a critical contextual factor for activating gap funding instruments.

In Table 5 (Panel B), we focus on the perceived effectiveness of internal gap funding programs, according to TTO managers distinguishing between internal USFs and POC programs. We did not find any statistically significant differences in perceived effectiveness, with an average value of 3.421 for internal USFs and 3.552 for internal POCs.

--- Include Table 5 around here ---

\subsection{Regression analyses}


In this section, we present the results of a multivariate analysis (Table 6) by detailing in Panel B the Probit regression models we used to analyze the likelihood that universities had (or did not have) an internal gap funding program (POC or USF) (Model 1), only a POC program (Model 2), and only a USF (Model 3). Then, we present the results of the regression model in which we analyzed differences in perceived effectiveness (1-5 Likert scale) of internal gap funding programs (Model 4), as reported by TTO managers.

As it is always the case in survey, the 128 respondents (regardless of whether they started an internal gap funding program) might not be representative of the overall population of 589 universities. We therefore started by addressing the potential issue of selection bias in two ways. First, we compared the distribution of respondents and non-respondents along two main variables available for both groups: the university's location in different European geographic areas and the university's research quality. Pearson $\chi^{2}$ was used to test whether our sample provides a good match to the respondents' distribution of the variables in the full list of universities in the initial sample. The Pearson $\chi 2$ test for the distribution by European geographic area equaled to 7.64 (p-value $<.1$ ), while that for the distribution by research quality equaled to $14.70(\mathrm{p}<.01)$. Second, we performed a Probit regression in which the dependent variable was an indicator of whether or not the individual responded to the survey, while the regressors were dummy variables for the university's European geographic area and university research quality. Panel A of Table 6 shows that some coefficient estimates (Southern Europe and University Research Quality) are different from zero in statistical terms. Therefore, with respect to the population, our sample seems to over-represent universities that are in the top ranking for research activity and are located in the south of Europe. These results are confirmed by the comparison tests we performed in Table 7 between the 128 universities represented by the survey respondents and the full population of 589 universities contacted through the survey.

To control for the effect of response bias in our sample we therefore run our regressions by correcting the results for selectivity through inverse probability weighting (Wooldridge, 2002). Each 
observation is weighted through an inverse probability procedure using the Probit regressions that predict the likelihood of being a respondent, as reported in Panel A of Table 6. The weights for each observation are given by the inverse of the predicted values of the same observation in the selection regression. For completeness, Panel B of Table 6 reports the results with the inclusion of the inverse probability weighting ${ }^{6}$.

We start by discussing the results on the university involvement in gap funding instruments (Models 1-3) and then we turn to the perceived effectiveness of these programs (Model 4). Models 1-3 of Panel B consistently indicate that the TTO size variable exerted a positive effect on the likelihood to activate a gap funding program (i.e., coefficients are statistically significant at the $10 \%$ level). This effect was more pronounced for POC programs $(0.011, \mathrm{p}<.05)$ compared with USFs $(0.005, \mathrm{p}<.1)$, and confirms our previous findings on the importance of maintaining a TTO with viable size - which appears critical not only to succeed in the complex TT process but also to be able to manage the related programs. In terms of university characteristics, contrary to our expectations we find only a marginal significance of research quality as an antecedent of the university's engagement in gap funding instruments and only in the case of USFs $(0.243, \mathrm{p}<.1)$. A possible explanation could be found in the characteristics of USFs with respect to POCs. As shown in Figure 1, USFs operate in a more downstream stage of the start-up development, require a more structured approach and higher financial needs, and are operated as portfolios of investments. A consistent and more valuable research pool might offer better opportunity to spread the risk and increase the likelihood of success of USFs. As for university size, no significant effects are recorded, suggesting that rather than the number of academic staff working at the university, it is the quality of the research performed that matters for the decision to activate gap funding programs.

\footnotetext{
${ }^{6}$ We found no substantial differences when comparing the results with and without the selectivity correction. The results without the correction for sample selection bias are available on request from the Authors.
} 
Overall the institutional and economic contexts supporting innovation are critical for university engagement in gap funding instruments, although the results are mixed. Regional Public Funding complement USFs (Model 2), but substitute for POCs (Model 3) and for general purpose funding gap programs (Model 1). This is consistent with the nature of several European Regional public funding scheme which are focused on the pre-competitive phases of development which are typical of POCs. The higher the level of dedicated local resources, the lower the need to fill the funding gap by Universities for pre-competitive innovation development and the greater the complementarity of USF initiatives dedicated to their commercial exploitation.

Universities located in more-innovative regions are embedded in a dynamic context that may be more amenable to exploit the results of commercialization activities backed by gap funding instruments as the positive and significant coefficient of the Regional High Tech Focus variable confirms $(0.001$, $\mathrm{p}<.05$ ). If we distinguish between POCs and USFs, however, this result holds only for POCs and not for USFs, which suggests that the local industrial base is critical to exploit pre-competitive technologies through licensing agreements or research contracts with industry, but is less relevant to support new ventures. The variable Regional Inventive Activity, based on a measure of patenting activity, on the contrary, is never significant in any of the three models, although consistent in terms of directionality. A more fine-grained information at the level of the specific projects funded could help understand better this result which might be due to targets outside of patent-intensive sectors.

Finally, the availability of $V C$ funding at the national level has only a positive effect, at the $10 \%$ level, in the first model, although the statistical significance disappears (at conventional levels) in Model 2 and Model 3. From such evidence, we thus cannot conclude that the extent of the national VC market is a critical pre-condition for the activation of gap funding programs by universities, although it impacts on their perceived effectiveness, as we will analyze later. If we take all this evidence together we see that the national development of the $\mathrm{VC}$ market has a positive influence in activating University level initiatives as perceived by the TTOs. Yet, their lack of impact on POCs is in line 
with the other findings pointing to a more localized exploitation of the results of precompetitive projects. The lack of impact on USFs is less clear, but could be interpreted as an indication of the level of international development of VC markets. USFs become an important complement to activate local search, but national co-investors are less relevant than international ones, especially for research driven initiatives in Universities where specific in depth expertise to understand the technologies are needed and normally require a scale and focus that national funds might not be able to sustain.

When we analyze the results of Model 4 related to the perceived effectiveness of internal gap funding instruments we find that it is higher when the internal gap funding program has been activated by a top-performing university in terms of research activity (coefficient $=1.078$, statistically significant at $10 \%$ ) and when the TTO has a good track record of experience (TTO Age $=0.08$ significant at 5\%) and it is an internal unit of the university (Internal TTO $=0.948$ significant at $10 \%$ ). The last two results on the effect of TTO's characteristics on perceived effectiveness need further clarification for their interpretation, given the use of a subjective measure of performance. First, although internal TTO governance may influence the effectiveness of gap funding programs due to a sort of proximity advantage between researchers and TTO managers, there could also be a bias driven by the deeper knowledge of the programs of internal TTOs and the steps taken during their implementation. Similarly, TTO age might be a signal of a biased perceived effectiveness variable, as we might imagine that the older the TTO, the higher the number of programs run and the better the perception of the effectiveness of the program conducted (given the absence of any objective measure). ${ }^{7}$

As far as environmental-level characteristics, as we have seen above, gap funding programs operating in countries with a strong availability of VC funding tend to obtain more positive evaluations (33.82, $\mathrm{p}<.05$ ). Moreover, the presence of regional public funding seems to contribute to the perceived effectiveness of these programs $(0.01, \mathrm{p}<.05)$. These two findings support the idea that the performance of gap funding programs activated by universities is perceived as effective in particular

\footnotetext{
${ }^{7}$ We would like to thank one of the Reviewers for pointing out this important issue.
} 
when the external eco-system provides opportunities for follow-on funding. This is in line with the goal of these programs, which are set up with the aim of making university technologies more qualified for attracting additional sources of funding so to complete the go-to-market process. This interpretation seems confirmed by the positive sign $(.0545, \mathrm{p}<.05)$ of the variable Regional GDP in Model 4. The Regional Inventive Activity variable, on the contrary, continues in Model 4 to offer unexpected results with a negative and significant coefficient $(-.0113, \mathrm{p}<.05)$, maybe suggesting that that the expectations of impact for such programs are particularly high in contexts characterized by relevant inventive activity.

--- Include Tables 6 and 7 around here ---

\subsection{Robustness check}

One of the main methodological concerns that can arise is the use of a subjective measure of performance assessed through a Likert scale. Indeed, Likert scales may be subject to distortion from several causes, such as: (i) avoidance of using extreme response categories (generally known as central tendency bias), (ii) attempt to portray the respondent's organization in a more favorable light (social desirability bias) and (iii) agreeing with statements as presented (acquiescence bias). For the purpose of our analyses, the first two distortions may occur. Table 8 shows the plot of the distribution of our Likert-based variable (Perceived Effectiveness), showing the presence of spikes around average levels of the dependent variable (approximately $42 \%$ of the observations have an average value of 3 ).

In light of this evidence, we performed two normality tests in accordance with the Shapiro-Wilk and Shapiro-Francia formulas (Shapiro-Wilk, 1965; Shapiro-Francia, 1972). The statistic provided by the two tests is the ratio of the best estimator of the variance to the usual corrected sum of squares estimator of the variance (W). The statistic is positive and less than or equal to one and when the probability is greater than 0.05 (the critical level), the data are expected to be normal. Applied to our data, both tests fail to reject the null hypothesis of normality ( $\mathrm{W}=0.97$ with $\mathrm{p}$-value $=0.57$ and $\mathrm{W}=0.99$ 
with p-value $=0.99$, respectively). Thus, we may assume that the assumption of normality of the variable Perceived Effectiveness is reasonably satisfied for our data and, for such reasons, we do believe that the abovementioned biases do not represent a serious issue for our analyses. The results of the normality tests are shown in Table 9.

--- Include Tables 8 and 9 around here ---

\section{DISCUSSION AND POLICY IMPLICATIONS}

The findings of our analyses help shed light on the critical factors that should guide universities in deciding whether to activate internal gap funding instruments, such as POC programs or USF, in order to help academic technologies transition into markets. They also suggest important implications for university managers and policy makers interested in enhancing the effectiveness of TT activities through dedicated funding instruments. In particular, the responses to our survey highlight a significant diffusion of gap funding instruments among universities: 56 out of 128 universities declared that they had activated some gap funding programs. However, a closer look at the data reveals that their diffusion at the university level is uneven across Europe. Their presence is relatively well-established in Nordic and Western European countries, where universities have more experience engaging in Third Mission activities. Conversely, they are relatively scarce (if not absent) in Southern and Eastern European countries.

Our study highlights some profound practical implications for understanding the conditions in which universities should implement these types of internal instruments. With regard to TTO- and university-level factors, two characteristics emerge as particularly critical: the size of the TTO and the research quality of the university. Our results suggest that a TTO must reach viable size before it can manage these types of gap funding programs. In our sample, the average number of TTO employees was approximately 15 for universities that had an internal gap funding measure. The availability of high-quality science at the university level is another important precondition, as clearly 
emerges from our analyses. The quality of the university research base guarantees a steady stream of high-potential companies and the possibility of developing a diversified portfolio of high-quality companies in which to invest, which is particular relevant for USFs, given their proximity to the commercialization stage of the valorization of university research. The combination of these two results - importance of TTO size and of university research quality - suggests that universities with small-scale TTOs and less prominent research levels, rather than directly activating and autonomously running their own funding programs, should consider collaborating with other universities or partnering with governments and regional authorities to promote bridging structures, which might create critical mass through bundled projects and technologies across institutions, lower operation costs, and engage more professional personnel. Collaborative or regional/national solutions should benefit single institutions that are less prominent in terms of TTO size and/or research quality. The ultimate goal is to increase the pool of candidates eligible for the program and thus enhance the likelihood of finding high-quality projects. Although the potential benefits of such solutions are clear, especially in terms of overcoming the limited ability of small or mid-sized universities, their potential costs also require consideration, especially as they relate to coordination costs, the presence of additional administrative layers, and conflict generation. Another interesting insight is related to the governance of the TTO. Our findings suggest that gap funding programs activated by universities are perceived as more effective by professionals belonging to an internal TTO. A possible explanation for this result may be related to the fact that internal TTOs benefit from proximity advantages with researchers and can interact more frequently with them, and thus, they perceive more strongly the benefits a gap funding program yields.

Regional high-tech specialization emerges as a statistically significant antecedent of the activation of gap funding instruments, in particular of POC programs. This suggests high-tech regions represent a lively context that may be more amenable to exploit the results of commercialization activities backed by such programs. The availability of regional funds has a complementary effect on USF programs, while substitutes for POCs ones. This is coherent with the nature and target of European regional 
innovation funds which focus more on pre-competitive innovations and suggest a wise decision taken by University in filling a targeted gap, as confirmed by the positive impact of the presence of regional funds on the perceived effectiveness of gap-funding programs. As far as the role of complementary VC funds at the national level the results are less clear. Overall, they positively affect the initiation of gap funding programs and are perceived as highly critical in terms of perceived effectiveness of the programs. Yet, they do not affect directly POC and USF programs. For the former they might be not critical given the stage of development, while for the latter they might act more as weak ties to international investors than as direct complements.

Taken together these results are consistent with the bridging role of gap funding instruments, aimed at increasing the investor-readiness of university technologies and preparing them for downstream funding rounds. The availability of follow-on funding, either from public or private sources, is therefore instrumental and perceived as an important component to guarantee the smooth progression of university technologies towards the market. Administrators of university gap funding programs should therefore try to establish and nurture fruitful and systematic linkages and collaborations with external investors, with the final goal to create an integrated and effective funding support system, well aware of the differences existing among the different alternatives and the importance of developing programs tailored to the specificities of the local conditions. The one size fit all approach where initiatives developed elsewhere are copied and imported will clearly bear no fruit.

Some limitations in our study offer opportunities for future research. Our descriptive survey-based evidence on gap funding programs suggests that they tend to be heterogeneous in several dimensions, such as fund size, amount of funding per project, and type of support activities, in addition to funding and funding sources. Incomplete data prevented us from analyzing in detail how the structural characteristics of gap funding programs determine their ultimate effectiveness. This point represents an important challenge for future research, which should seek deeper insights into the critical success factors for the design and implementation of such financial instruments. Furthermore, we were not able to capture the level of expertise of the TTO staff, certainly a critical element for understanding 
the activation and the effectiveness of gap funding programs. While scale matters in TTOs, the ability to support such programs with a team of professionals who possess adequate skills and experience to select, support, and monitor the funded companies/projects is clearly important and we were not able to assess it. Future research could try to integrate some variables measuring the experience and competences of the TTO staff to provide a more comprehensive picture of the TTO-level characteristics influencing the development of gap funding programs.

We used a simple and rather crude measure of perceived effectiveness with a limited number of observations, so our results should only be considered tentative. Additional studies should investigate effectiveness in a more robust way using objective, quantitative measures of success at the recipient company or project level (Croce et al., 2014; Munari et al., 2015). Ideally, research should analyze the share of POC- versus USF-backed projects that attract additional funding from other sources (and the amounts), such as external public bodies (i.e., regional or national governments or innovation agencies, such as EU funding), business angels, VC investors, and industry partners. As the ultimate results of such programs depend on the ability of the supported technologies to reach commercialization and generate returns in the form of commercial and R\&D contracts with industry, additional outcome indicators for POC- or USF-backed projects could include revenues from licensing deals or financial income from selling shares of university spin-offs. In terms of methodological approaches, researchers should compare the commercialization success of projects funded by university-related gap funding instruments with that of a control group of projects backed by other funding instruments or unfunded projects in order to disentangle any additional effect of such programs.

In spite of all its limitations, our study represents a first empirical effort, at the European level, to assess the influences on and the perceived effectiveness of an innovative set of gap funding instruments, which represent important levers for commercializing science-based inventions. We are confident that future studies could build on our efforts to further advance our theoretical knowledge 
of the funding gap problem to design more effective policies and to support Universities in their technology transfer strategies.

Acknowledgments. Financial support from the EIBURS program of the European Investment Bank (FinKT project) and the Italian Ministry of University and Research (CUP 2010H37KAW 20132016) are gratefully acknowledged. 


\section{REFERENCES}

Audretsch, David B., Bönte, Werner, \& Mahagaonkar, Prashanth, 2012. "Financial signaling by innovative nascent ventures: The relevance of patents and prototypes," Research Policy, Elsevier, vol. 41(8), pages 1407-1421.

Auerswald, P.E. Branscomb LM, 2003. "Valleys of death and Darwinian seas: Financing the invention to innovation transition in the United States", Journal of Technology Transfer, 28 (3), 227-239.

Azagra-Caro JM, Archontakis F, Gutiérrez-Gracia A, Fernández-de-Lucio I. 2006. Faculty support for the objectives of university-industry relations versus degree of R\&D cooperation: The importance of regional absorptive capacity. Research Policy, 35 (1), 37-55.

Baldini, N. 2010. Do royalties really foster university patenting activity? An answer from Italy. Technovation, 30 (2), 109-116.

Battilana, J., Dorado, S. 2010. Building sustainable hybrid organizations: the case of commercial microfinance organizations. Academy of Management Journal, 53: 1419-1440

Benner, M. U. Sandstrom. 2000. Institutionalizing the triple helix: research funding and norms in the academic system. Research Policy, 29 (2), pp. 291-301.

Berman, E. 2012. Explaining the move toward the market in US academic science: how institutional logics can change without institutional entrepreneurs. Theory and Society. 41(3): 261-299.

Bonaccorsi A, Colombo M, Guerini M, Rossi-Lamastra C. 2014. The impact of local and external university knowledge on the creation of knowledge-intensive firms: Evidence from the Italian case. Small Business Economics. 43(2): 261-287.

Bradley S.R., Hayter, C.S., Link A.N. 2013. Proof of Concept Centers in the United States: an exploratory look. Journal of Technology Transfer. 38(4): 349-381.

Colombo, M.G., Grilli, L. 2010. On growth drivers of high-tech start-ups: Exploring the role of founders' human capital and venture capital. Journal of Business Venturing, 25 (6), pp. 610-626.

Croce, A., Grilli, L., Murtinu, S. 2014. Venture Capital Enters in Academia: a Look at University- Managed Funds. Journal of Technology Transfer. 39(5): 688-715.

Cumming, D.J. 2007. Government policy towards entrepreneurial finance: Innovation investment funds. Journal of Business Venturing, 22, 193-235.

Daraio, C., Bonaccorsi, A., Geuna, A., Lepori, B., Bach L, Bogetoft P. 2011. The European university landscape: A micro characterization based on evidence from the Aquameth project. Research Policy. 40: 148-164.

Darcy, J, Kraemer-Eis H, Guellec, D, Debande, O, (2009). Financing Technology Transfer. EIB Papers, Vol. 14, No. 2, pp. 54-73, 2009.

Debackere, K., Veugeulers, R. 2005. The role of academic technology transfer organizations in improving industry science links. Research Policy, 34, 321-342.

DiGregorio, D., Shane, S., 2003. Why some universities generate more TLO start-ups than others? Research Policy 32 (2), c209-227

DiMaggio, P. J., Powell, W. W. 1983. The Iron Cage Revisited: Institutional Isomorphism and Collective Rationality in Organizational Fields. American Sociological Review, 48(2): 147-160.

Etzkowitz H, 2003. Innovation in innovation: The triple helix of university-industry-government relations. Social Science Information, 42 (3), 293-337.

Fini, R., Grimaldi, R., Santoni, S., Sobrero, M. 2011. Complements or substitutes? The role of universities and local context in supporting the creation of academic spin-offs. Research Policy, 40(8), 1113-1127.

Freund, R. J. and W. J. Wilson (1998), Regression Analysis: Statistical Modeling of a Response Variable. Academic Press: San Diego, CA.

Friedman, J., Silberman, J., 2003. University technology transfer: do incentives, management and location matter? Journal of Technology Transfer 28, 17-30.

Geuna, Aldo \& Rossi, Federica, 2011. Changes to university IPR regulations in Europe and the impact on academic patenting. Research Policy, vol. 40(8), pages 1068-1076.

Giuri, P., Munari, F., Pasquini, M. 2013. "What Determines University Patent Commercialization? Empirical Evidence on the Role of IPR Ownership", Industry and Innovation, 20 (5), pp. 488-502

Gulbranson, C.A., Audretsch, D.B. 2008. Proof of concept centers: accelerating the commercialization of university innovation. The Journal of Technology Transfer, 33(2): 249-258.

Kochenkova, A., Grimaldi, R., Munari, F. 2015 Public policy measures in support of knowledge transfer activities: a review of the academic literature, Journal of Technology Transfer, forthcoming.

Lerner, J. 2009. Boulevard of Broken Dreams: Why Public Efforts to Boost Entrepreneurship and Venture Capital Have Failed - and What to Do about It. Princeton University Press, Princeton, NJ.

Lockett, A., Wright, M. 2005. Resources, capabilities, risk capital and the creation of university spin-out companies. Research Policy, 34: 1043-1057.

Luukkonen, T., Deschryvere, M., Bertoni, F. 2013. The value added by government venture capital funds compared with independent venture capital funds. Technovation, 33(4-5), 154-162. 
Maia, C., Claro, J. 2013. The role of a Proof of Concept Center in a university ecosystem: an exploratory study. Journal of Technology Transfer, 38 (5), 641-650.

Markman, G. D, Phan, P. H., Balkin, D. B., Gianiodis, P. T. 2005. Entrepreneurship and university-based technology transfer. Journal of Business Venturing, 20(2): 241-263.

Mazzucato, M. 2013. Financing innovation: creative destruction vs. destructive creation. Industrial and Corporate Change (2013) 22 (4): 851-867.

Meyer, J. W., \& Rowan, B. 1977. Institutionalized organizations: Formal structure as myth and ceremony. American Journal of Sociology, 83(2): 340-363.

Munari, F., Pasquini, M., Toschi, L. 2015. From the lab to the stock market? The characteristics and impact of universityoriented seed funds in Europe, Journal of Technology Transfer, 40(6): 948-975.

Munari, F., Rasmussen, E., Toschi, L., Villani, E. (2016). Determinants of the university technology transfer policy-mix: a cross-national analysis of gap-funding instruments. Journal of Technology Transfer, 41(6): 1377-1405.

Munari, F. and Toschi, L. 2011. Do venture capitalists have a bias against investment in academic spin-offs? Evidence from the micro- and nanotechnology sector in the UK. Industrial and Corporate Change, 20(2): 397-432.

Munari, F. and Toschi, L. 2015. Assessing the impact of public venture capital programmes in the United Kingdom: Do regional characteristics matter? Journal of Business Venturing, 30(2): 205-226.

Murray G 2007. Venture capital and government policy. In H. Landstrom (Ed.), Handbook of research on venture capital. Cheltenham, UK: Edward Elgar Publishing.

Murray, G, Sheila, E., Evans, W.N., Schwab, R.M. 1998. Education-Finance Reform and the Distribution of Education Resources, American Economic Review, 88(4): 789-812.

O'Shea RP, Allen TJ, Chevalier A, Roche F. 2005. Entrepreneurial orientation, technology transfer and spinoff performance of US universities. Research Policy, 34 (7): 994-1009.

Owen-Smith J, Powell WW, 2001. To patent or not: Faculty decisions and institutional success at technology transfer. The Journal of Technoloy Transfer, 26: 99-114.

Perkmann M, Tartari V, McKelvey M, et al. 2013. Academic engagement and commercialisation: A review of the literature on university-industry relations. Research Policy 42: 423-442.

Phan, P. H., Siegel, D. S., Wright, M. 2005. Science parks and incubators: Observations, synthesis and future research. Journal of Business Venturing, 20(2): 165-182.

Rasmussen, E., Mosey, S., Wright, M. 2011. The evolution of entrepreneurial competencies: A longitudinal study of university spin-off venture emergence. Journal of Management Studies, 48(6): 1314- 1345.

Rasmussen E, Sorheim R. 2012. How governments seek to bridge the financing gap for university spin-offs: Proof-ofconcept, pre-seed, and seed funding. Technology Analysis and Strategic Management, 24(7): 663-678.

Schoen, A., van Pottelsberghe de la Potterie, B., Henkel, J. 2014. Governance typology of universities' technology transfer processes. Journal of Technology Transfer, 39: 435-453.

Shane, S., Stuart, T. 2003. Organizational Endowments and the Performance of University Start-ups. Management Science. 48(1):154-170.

Shapiro, SS, Francia RS. 1972. An approximate analysis of variance test for normality. Journal of the American Statistical Association. 67: 215-216.

Shapiro, SS, Wilk, MB. 1965. An analysis of variance test for normality (complete samples). Biometrika 52: 591-611.

Siegel, D., Waldman, D., Link, A., 2003. Assessing the impact of organizational practices on the relative productivity of university technology transfer offices: an exploratory study. Research Policy 32 (1): 27-48.

Wooldridge, J.M., 2002. Econometric Analysis of Cross Section and Panel Data. MIT Press.

Wright, M., Lockett, A., Clarysse, B., Binks, M. 2006. University spin-out companies and venture capital. Research Policy 35(4): 481-501. 
TABLES AND FIGURES

Table 1. Comparison of POC and USF programs

\begin{tabular}{|l|c|c|}
\hline & $\begin{array}{c}\text { University-Related Proof-of-Concept } \\
\text { Programs }\end{array}$ & University-Related Seed Funds \\
\hline Objective & $\begin{array}{c}\text { Evaluate and support the technical } \\
\text { feasibility and commercial potential of } \\
\text { early stage technologies generated by } \\
\text { universities and PROs }\end{array}$ & $\begin{array}{c}\text { Provide capital to university and PRO start- } \\
\text { ups to assist the early formation of new } \\
\text { company creation and early growth }\end{array}$ \\
\hline Focus of investment & $\begin{array}{c}\text { Primarily projects by individual } \\
\text { researchers or research teams }\end{array}$ & Primarily university and PRO start-ups \\
\hline Investments typology & $\begin{array}{c}\text { Typically grants, but other forms are } \\
\text { possible (i.e., loan, repayment schemes) }\end{array}$ & $\begin{array}{c}\text { Typically equity based, but other forms are } \\
\text { possible (i.e., convertible loan) }\end{array}$ \\
\hline Investment stage & $\begin{array}{c}\text { Pre-seed stage (typically before company } \\
\text { formation) }\end{array}$ & $\begin{array}{c}\text { Seed and early stage (business formation and } \\
\text { early growth) }\end{array}$ \\
\hline
\end{tabular}


Table 2. Variable definitions

This table presents the definitions of the main variables included in the regression models.

\begin{tabular}{|c|c|c|}
\hline Variable & Description & Source \\
\hline $\begin{array}{l}\text { Internal Gap } \\
\text { Funding } \\
\text { Program }\end{array}$ & $\begin{array}{l}\text { Dummy variable that takes a value of } 1 \text { if the university has activated a "gap } \\
\text { funding" program as of May 2013, } 0 \text { otherwise. }\end{array}$ & FinKT Survey \\
\hline Internal USF & $\begin{array}{l}\text { Dummy variable that takes a value of } 1 \text { if the university has activated a USF } \\
\text { program as of May 2013, } 0 \text { otherwise. }\end{array}$ & FinKT Survey \\
\hline Internal POC & $\begin{array}{l}\text { Dummy variable that takes a value of } 1 \text { if the university has activated a POC } \\
\text { program as of May 2013, } 0 \text { otherwise. }\end{array}$ & FinKT Survey \\
\hline $\begin{array}{l}\text { Perceived } \\
\text { Effectiveness }\end{array}$ & $\begin{array}{l}\text { Perceived effectiveness of the "gap funding" measures in promoting } \\
\text { technology transfer, measured on a } 1-5 \text { Likert Scale. }\end{array}$ & FinKT Survey \\
\hline TTO Age & Age of the TTO, expressed in years, on May 2013. & FinKT Survey \\
\hline Internal TTO & $\begin{array}{l}\text { Dummy variable that takes a value of } 1 \text { if the TTO is an internal department of } \\
\text { the university, } 0 \text { otherwise. }\end{array}$ & FinKT Survey \\
\hline TTO Size & Size of the TTO, expressed as number of personnel working at the TTO in 2012. & FinKT Survey \\
\hline University Size & $\begin{array}{l}\text { Size of the university, expressed as number of personnel working at the } \\
\text { university in } 2008 \text {. }\end{array}$ & $\begin{array}{l}\text { Eumida and Web } \\
\text { Search }\end{array}$ \\
\hline $\begin{array}{l}\text { University } \\
\text { Research } \\
\text { Quality }\end{array}$ & $\begin{array}{l}\text { Dummy variable equal to } 1 \text { if the university is in the top } 200 \text { Times Higher } \\
\text { Education (THE) Ranking of research universities, } 0 \text { otherwise. }\end{array}$ & THE Ranking \\
\hline $\begin{array}{l}\text { Technical/Medic } \\
\text { al University }\end{array}$ & $\begin{array}{l}\text { Dummy variable that takes a value of } 1 \text { if the university is a technical or medical } \\
\text { university, } 0 \text { if the university is generalist. }\end{array}$ & Web Search \\
\hline $\begin{array}{l}\text { Public } \\
\text { University }\end{array}$ & Dummy variable that takes a value of 1 if the university is public, 0 otherwise. & $\begin{array}{l}\text { Eumida and Web } \\
\text { Search }\end{array}$ \\
\hline University Age & Age of the university, expressed in years, on May 2013. & $\begin{array}{l}\text { Eumida and Web } \\
\text { Search }\end{array}$ \\
\hline $\begin{array}{l}\text { Professor } \\
\text { Privilege }\end{array}$ & $\begin{array}{l}\text { Dummy variable equal to } 1 \text { if the national legislation regulating patent } \\
\text { ownership on academic inventions is "professor privilege", } 0 \text { otherwise (" } \\
\text { institutional regime"). }\end{array}$ & Web Search \\
\hline Regional GDP & $\begin{array}{l}\text { Gross domestic product (GDP), expressed as Euro per inhabitant, at current } \\
\text { market prices by NUTS } 2 \text { regions on December } 2013 \text {. }\end{array}$ & Eurostat \\
\hline $\begin{array}{l}\text { Regional Public } \\
\text { Funding }\end{array}$ & $\begin{array}{l}\text { Total intramural R\&D expenditure, expressed as Euro per inhabitant, by NUTS } \\
2 \text { regions on December } 2013 \text {. }\end{array}$ & Eurostat \\
\hline $\begin{array}{l}\text { Regional High } \\
\text { Tech Focus }\end{array}$ & $\begin{array}{l}\text { Employment in technology and knowledge-intensive sectors, expressed in } \\
\text { thousands, by NUTS } 2 \text { regions on December } 2013 \text {. }\end{array}$ & Eurostat \\
\hline $\begin{array}{l}\text { Regional } \\
\text { Inventive } \\
\text { Activity }\end{array}$ & $\begin{array}{l}\text { Patenting activity, expressed as number of patent applications to the EPO per } \\
\text { inhabitant by NUTS } 2 \text { regions on December } 2013 \text {. }\end{array}$ & Eurostat \\
\hline $\begin{array}{l}\text { National VC } \\
\text { Funding }\end{array}$ & $\begin{array}{l}\text { Venture Capital investments, expressed as percentage of GDP, by country on } \\
\text { December } 2013 \text {. }\end{array}$ & Eurostat \\
\hline
\end{tabular}




\section{Table 3. Summary Statistics (total sample and breakdown by group of countries}

This table summarizes the data for the universities of the full sample and the different European areas represented (Eastern, Northern, Southern, and Western Europe). The number of observations, the mean, the standard deviation, the minimum, and the maximum values are provided. For definitions of the variables, see Table 2.

\begin{tabular}{|c|c|c|c|c|c|c|c|c|c|c|c|c|c|c|c|c|c|c|}
\hline & $\begin{array}{c}\text { Internal Gap } \\
\text { Funding } \\
\text { Program } \\
\text { (dummy) }\end{array}$ & $\begin{array}{l}\text { Internal } \\
\text { POC } \\
\text { (dummy) }\end{array}$ & $\begin{array}{l}\text { Internal } \\
\text { USF } \\
\text { (dummy) }\end{array}$ & $\begin{array}{c}\text { Perceived } \\
\text { Effective } \\
\text { ness } \\
\text { (5 Likert } \\
\text { scale) }\end{array}$ & $\begin{array}{c}\text { TTO } \\
\text { Age } \\
\text { (years) }\end{array}$ & $\begin{array}{c}\text { Internal } \\
\text { TTO } \\
\text { (dummy) }\end{array}$ & $\begin{array}{c}\text { TTO } \\
\text { Size } \\
\text { (units) }\end{array}$ & $\begin{array}{c}\text { University } \\
\text { Size } \\
\text { (units) }\end{array}$ & $\begin{array}{c}\text { University } \\
\text { Quality } \\
\text { (dummy) }\end{array}$ & $\begin{array}{r}\text { Specialist } \\
\text { University } \\
\text { (dummy) }\end{array}$ & $\begin{array}{c}\text { Public } \\
\text { University } \\
\text { (dummy) }\end{array}$ & $\begin{array}{c}\text { University } \\
\text { Age } \\
\text { (years) }\end{array}$ & $\begin{array}{l}\text { Professor } \\
\text { Privilege } \\
\text { (dummy) }\end{array}$ & $\begin{array}{c}\begin{array}{c}\text { Regional } \\
\text { GDP }\end{array} \\
\text { ( } € \text { per } \\
\text { inhabitant) }\end{array}$ & $\begin{array}{c}\text { Regional } \\
\text { Public } \\
\text { Funding } \\
\text { (€ per } \\
\text { inhabitant) }\end{array}$ & $\begin{array}{c}\begin{array}{c}\text { Regional } \\
\text { High Tech } \\
\text { Focus }\end{array} \\
\text { (units) }\end{array}$ & $\begin{array}{c}\text { Regional } \\
\text { Inventive } \\
\text { Activity } \\
\text { (units per } \\
\text { inhabitant) }\end{array}$ & $\begin{array}{c}\text { National } \\
\text { VC } \\
\text { Funding } \\
\\
\text { (\% on } \\
\text { GDP) }\end{array}$ \\
\hline \multicolumn{19}{|c|}{ Full Sample } \\
\hline Obs & 128 & 128 & 128 & 48 & 128 & 128 & 128 & 128 & 128 & 128 & 128 & 128 & 128 & 128 & 128 & 128 & 128 & 128 \\
\hline Mean & 0.430 & 0.398 & 0.234 & 3.5 & 11.078 & 0.852 & 10.891 & 2879.234 & 0.242 & 0.250 & 0.938 & 182.875 & 0.211 & 29.989 & 85.916 & 1217.461 & 68.323 & 0.026 \\
\hline$S D$ & 0.497 & 0.492 & 0.425 & 0.85 & 7.922 & 0.357 & 13.267 & 2170.599 & 0.430 & 0.435 & 0.243 & 203.545 & 0.410 & 14.932 & 92.552 & 865.075 & 66.123 & 0.020 \\
\hline Min & 0 & 0 & 0 & 1 & 0 & 0 & 1 & 180 & 0 & 0 & 0 & 1 & 0 & 6.125 & 0.215 & 173 & 1.025 & 0.003 \\
\hline $\operatorname{Max}$ & 1 & 1 & 1 & 5 & 46 & 1 & 85 & 11606 & 1 & 1 & 1 & 924 & 1 & 81.212 & 452.417 & 5255 & 324.611 & 0.092 \\
\hline \multicolumn{19}{|c|}{ Eastern European Area } \\
\hline Obs & 12 & 12 & 12 & 1 & 12 & 12 & 12 & 12 & 12 & 12 & 12 & 12 & 12 & 12 & 12 & 12 & 12 & 12 \\
\hline Mean & 0.250 & 0.167 & 0.083 & 3 & 4.750 & 0.917 & 8.750 & 1916.667 & 0.000 & 0.417 & 0.917 & 66.750 & 0.000 & 13.634 & 67.881 & 815.500 & 19.443 & 0.017 \\
\hline$S D$ & 0.452 & 0.389 & 0.289 & 0 & 4.093 & 0.289 & 6.690 & 1064.866 & 0.000 & 0.515 & 0.289 & 32.974 & 0.000 & 8.523 & 36.061 & 325.632 & 24.480 & 0.013 \\
\hline Min & 0 & 0 & 0 & 3 & 1 & 0 & 2 & 400 & 0 & 0 & 0 & 1 & 0 & 6.694 & 3.133 & 440 & 1.025 & 0.004 \\
\hline $\operatorname{Max}$ & 1 & 1 & 1 & 3 & 14 & 1 & 22 & 3905 & 0 & 1 & 1 & 124 & 0 & 29.989 & 124.172 & 1311 & 68.323 & 0.038 \\
\hline \multicolumn{19}{|c|}{ Northerns European Area } \\
\hline Obs & 37 & 37 & 37 & 24 & 37 & 37 & 37 & 37 & 37 & 37 & 37 & 37 & 37 & 37 & 37 & 37 & 37 & 37 \\
\hline Mean & 0.730 & 0.703 & 0.486 & 3.46 & 12.811 & 0.811 & 13.919 & 3198.568 & 0.432 & 0.162 & 0.946 & 161.541 & 0.162 & 37.119 & 77.612 & 915.243 & 66.868 & 0.041 \\
\hline$S D$ & 0.450 & 0.463 & 0.507 & 0.66 & 8.900 & 0.397 & 15.091 & 2032.949 & 0.502 & 0.374 & 0.229 & 127.885 & 0.374 & 18.230 & 96.141 & 461.384 & 51.313 & 0.019 \\
\hline Min & 0 & 0 & 0 & 2 & 0 & 0 & 1 & 253 & 0 & 0 & 0 & 5 & 0 & 8.906 & 0.215 & 173 & 2.546 & 0.021 \\
\hline $\operatorname{Max}$ & 1 & 1 & 1 & 5 & 46 & 1 & 60 & 9272 & 1 & 1 & 1 & 535 & 1 & 81.212 & 452.417 & 2346 & 167.145 & 0.08 \\
\hline \multicolumn{19}{|c|}{ Southern European Area } \\
\hline Obs & 35 & 35 & 35 & 3 & 35 & 35 & 35 & 35 & 35 & 35 & 35 & 35 & 35 & 35 & 35 & 35 & 35 & 35 \\
\hline Mean & 0.057 & 0.029 & 0.057 & 2.33 & 9.429 & 0.914 & 6.257 & 2912.914 & 0.029 & 0.029 & 0.943 & 224.657 & 0.600 & 24.918 & 43.003 & 1739.171 & 45.402 & 0.007 \\
\hline$S D$ & 0.236 & 0.169 & 0.236 & 1.53 & 5.237 & 0.284 & 5.982 & 2087.874 & 0.169 & 0.169 & 0.236 & 283.968 & 0.497 & 6.311 & 39.347 & 1071.014 & 36.873 & 0.007 \\
\hline Min & 0 & 0 & 0 & 1 & 2 & 0 & 1 & 180 & 0 & 0 & 0 & 14 & 0 & 13.058 & 5.962 & 177 & 3.319 & 0.003 \\
\hline $\operatorname{Max}$ & 1 & 1 & 1 & 4 & 24 & 1 & 26 & 9222 & 1 & 1 & 1 & 924 & 1 & 33.536 & 215.559 & 4298 & 114.296 & 0.026 \\
\hline \multicolumn{19}{|c|}{ Western European Area } \\
\hline Obs & 44 & 44 & 44 & 20 & 44 & 44 & 44 & 44 & 44 & 44 & 44 & 44 & 44 & 44 & 44 & 44 & 44 & 44 \\
\hline Mean & 0.523 & 0.500 & 0.250 & 3.75 & 12.659 & 0.818 & 12.614 & 2846.432 & 0.318 & 0.455 & 0.932 & 199.250 & 0.000 & 32.486 & 131.951 & 1166.227 & 101.112 & 0.030 \\
\hline$S D$ & 0.505 & 0.506 & 0.408 & 0.85 & 8.635 & 0.390 & 16.116 & 2523.892 & 0.471 & 0.504 & 0.255 & 196.938 & 0.000 & 13.585 & 110.391 & 866.033 & 85.348 & 0.017 \\
\hline Min & 0 & 0 & 0 & 2 & 1 & 0 & 1 & 290 & 0 & 0 & 0 & 3 & 0 & 6.125 & 0.946 & 241 & 2.178 & 0.009 \\
\hline $\operatorname{Max}$ & 1 & 1 & 1 & 5 & 41 & 1 & 85 & 11606 & 1 & 1 & 1 & 647 & 0 & 78.247 & 414.325 & 5255 & 324.611 & 0.092 \\
\hline
\end{tabular}




\section{Table 4. Correlation matrix}

This table presents correlations across selected variables for our sample of 128 observations. Correlations significant at the $1 \%$ level are highlighted in underline font.

\begin{tabular}{|c|c|c|c|c|c|c|c|c|c|c|c|c|c|c|c|c|c|c|}
\hline & & 1. & 2. & 3. & 4. & 5. & 6. & 7. & 8. & 9. & 10. & 11. & 12. & 13. & 14. & 15. & 16 & 17. \\
\hline 1 & Internal Gap Funding Program & 1 & & & & & & & & & & & & & & & & \\
\hline 2 & Internal USF & $\underline{0.637}$ & 1 & & & & & & & & & & & & & & & \\
\hline 3 & Internal POC & $\underline{0.905}$ & $\underline{0.492}$ & 1 & & & & & & & & & & & & & & \\
\hline 4 & University Size & 0.077 & 0.125 & 0.106 & 1 & & & & & & & & & & & & & \\
\hline 5 & University research Quality & $\underline{0.357}$ & $\underline{0.376}$ & $\underline{0.397}$ & $\underline{0.400}$ & 1 & & & & & & & & & & & & \\
\hline 6 & Technical/Medical University & 0.082 & 0.107 & 0.009 & -0.168 & 0.053 & 1 & & & & & & & & & & & \\
\hline 7 & Public University & -0.037 & -0.010 & -0.054 & 0.061 & -0.005 & 0.075 & 1 & & & & & & & & & & \\
\hline 8 & University Age & -0.004 & -0.020 & -0.021 & $\underline{0.487}$ & 0.176 & -0.203 & 0.067 & 1 & & & & & & & & & \\
\hline 9 & TTO Age & 0.135 & 0.135 & 0.132 & 0.080 & $\underline{0.256}$ & 0.067 & -0.051 & 0.021 & 1 & & & & & & & & \\
\hline 10 & Internal TTO & -0.082 & -0.080 & -0.064 & 0.041 & -0.123 & -0.013 & -0.017 & -0.002 & -0.171 & 1 & & & & & & & \\
\hline 11 & TTO Size & $\underline{0.290}$ & $\underline{0.278}$ & $\underline{0.285}$ & 0.076 & $\underline{0.306}$ & 0.103 & -0.141 & -0.115 & $\underline{0.391}$ & $\underline{-0.258}$ & 1 & & & & & & \\
\hline 12 & Professor Privilege & $\underline{-0.255}$ & -0.105 & -0.225 & 0.136 & -0.158 & -0.166 & 0.054 & 0.211 & -0.134 & 0.108 & $\underline{-0.235}$ & 1 & & & & & \\
\hline 13 & Regional GDP & $\underline{0.319}$ & $\underline{0.275}$ & $\underline{0.345}$ & 0.187 & $\underline{0.440}$ & 0.056 & -0.043 & 0.004 & 0.173 & -0.165 & $\underline{0.322}$ & 0.003 & 1 & & & & \\
\hline 14 & Regional Public Funding & 0.062 & 0.221 & 0.023 & 0.034 & 0.218 & $\underline{0.234}$ & -0.029 & -0.086 & 0.109 & -0.049 & 0.190 & -0.226 & $\underline{0.426}$ & 1 & & & \\
\hline 15 & Regional High Tech Focus & -0.080 & 0.041 & -0.080 & 0.139 & 0.030 & 0.101 & 0.034 & 0.082 & 0.077 & 0.119 & -0.078 & $\underline{0.235}$ & 0.124 & 0.022 & 1 & & \\
\hline 16 & Regional Inventive Activity & 0.1320 & $\underline{0.2295}$ & 0.1571 & 0.1626 & 0.1998 & $\underline{0.2393}$ & -0.0265 & 0.0144 & 0.0941 & 0.0867 & 0.0867 & 0.0578 & $\underline{0.4121}$ & $\underline{0.4915}$ & 0.1927 & 1 & \\
\hline 17 & National VC Funding & $\underline{0.443}$ & $\underline{0.240}$ & $\underline{0.476}$ & 0.072 & $\underline{0.306}$ & 0.018 & -0.084 & -0.074 & 0.090 & -0.031 & 0.181 & $\underline{-0.304}$ & $\underline{0.451}$ & 0.130 & $\underline{-0301}$ & $\underline{0.231}$ & 1 \\
\hline
\end{tabular}




\section{Table 5. A comparison of universities with and without gap funding programs}

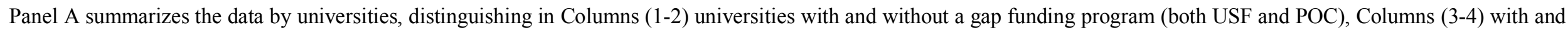

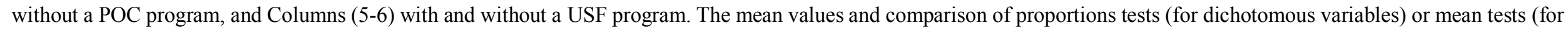

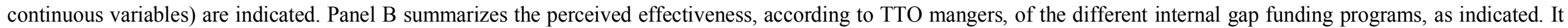
also contains the mean values and comparisons of mean tests.

\begin{tabular}{|c|c|c|c|c|c|c|c|c|c|c|c|c|}
\hline \multirow[t]{2}{*}{ Panel A } & (1) & (2) & \multicolumn{2}{|c|}{ (2) - (1) } & (3) & (4) & \multicolumn{2}{|c|}{ (4) - (3) } & (5) & (6) & \multicolumn{2}{|c|}{$(6)-(5)$} \\
\hline & $\begin{array}{c}\text { Universities with a } \\
\text { Gap Funding } \\
\text { Program } \\
\end{array}$ & $\begin{array}{c}\text { Universities } \\
\text { without a Gap } \\
\text { Funding Program }\end{array}$ & \multicolumn{2}{|c|}{ Difference tests } & $\begin{array}{l}\text { Universities } \\
\text { with POC } \\
\text { Program }\end{array}$ & $\begin{array}{c}\text { Universities } \\
\text { without POC } \\
\text { Program }\end{array}$ & \multicolumn{2}{|c|}{ Difference tests } & $\begin{array}{l}\text { Universities } \\
\text { with USF } \\
\text { Program }\end{array}$ & $\begin{array}{c}\text { Universities } \\
\text { without USF } \\
\text { Program }\end{array}$ & \multicolumn{2}{|c|}{ Difference tests } \\
\hline \multirow[t]{2}{*}{ Number of observations } & 56 & 72 & & & 51 & 77 & & & 30 & 98 & & \\
\hline & Mean & Mean & Proportion & Mean & Mean & Mean & Proportion & Mean & Mean & Mean & Proportion & Mean \\
\hline $\begin{array}{l}\text { TTO Age } \\
\text { Internal TTO }\end{array}$ & $\begin{array}{l}12.309 \\
0.818\end{array}$ & $\begin{array}{c}10.151 \\
0.876\end{array}$ & 0.059 & 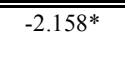 & $\begin{array}{l}12.353 \\
0.824\end{array}$ & $\begin{array}{l}10.234 \\
0.870\end{array}$ & 0.047 & "-2.119* & $\begin{array}{l}13.000 \\
0.800\end{array}$ & $\begin{array}{l}10.490 \\
0.867\end{array}$ & 0.067 & $-2.510^{*}$ \\
\hline TTO Size & 15.309 & 7.562 & & $-7.747 * * *$ & 15.510 & 7.831 & & $-7.679 * * *$ & 17.533 & 8.857 & & $-8.676^{* * *}$ \\
\hline University Size & 3069.982 & 2735.521 & & -334.4613 & 3160.118 & 2693.195 & & -466.923 & 3368.933 & 2729.327 & & $-639.607^{*}$ \\
\hline University Research Quality & 0.418 & 0.110 & $-0.309^{* * *}$ & & 0.451 & 0.104 & $-0.347^{* * *}$ & & 0.533 & 0.153 & $-0.380^{* * *}$ & \\
\hline Technical/Medical University & 0.291 & 0.219 & -0.071 & & 0.255 & 0.247 & -0.008 & & 0.333 & 0.224 & -0.109 & \\
\hline Public University & 0.927 & 0.945 & 0.018 & & 0.922 & 0.948 & 0.026 & & 0.933 & 0.939 & 0.005 & \\
\hline University Age & 181.909 & 183.603 & & 1.694 & 177.608 & 186.364 & & 8.756 & 175.700 & 185.071 & & 9.371 \\
\hline Professor Privilege & 0.091 & 0.301 & $0.210^{* *}$ & & 0.098 & 0.286 & $0.188 * *$ & & 0.133 & 0.235 & 0.101 & \\
\hline Regional GDP & 35.448 & 25.875 & & $-9.579^{* * *}$ & 36.284 & 25.819 & & $-10.465^{* * *}$ & 37.378 & 27.727 & & $-9.652^{* * *}$ \\
\hline Regional Public Funding & 92.481 & 80.969 & & -11.512 & 88.478 & 84.219 & & -4.259 & 122.652 & 74.670 & & $-47.982 * *$ \\
\hline Regional High Tech Focus & 1138.345 & 1277.068 & & 138.723 & 1133.196 & 1273.273 & & 140.077 & 1280.867 & 1198.051 & & -82.816 \\
\hline Regional Inventive Activity & 78.179 & 60.658 & & $-17.520^{*}$ & 81.040 & 59.901 & & $-21.140^{*}$ & 95.644 & 59.960 & & $-35.684 * * *$ \\
\hline National VC Funding & 0.036 & 0.018 & & $-0.018^{* * *}$ & 0.037 & 0.018 & & $-0.019^{* * *}$ & 0.034 & 0.023 & & $-0.011 * *$ \\
\hline
\end{tabular}

\begin{tabular}{c|cc|c}
\hline Panel B & (1) & (2) & (2-) - (1) \\
\hline & Internal USF & Internal POC & Difference tests \\
& & & \\
\hline Number of observations & 19 & 29 & \\
\hline \hline & Mean & Mean & Mean \\
\hline \hline Perceived Effectiveness & 3.421 & 3.552 & 0.131 \\
\hline
\end{tabular}




\section{Table 6. Regression analyses}

This table presents (Panel A) Probit regression of the probability of being a respondent of the survey and (Panel B, Models 1-3) Probit analyses (corrected for the inverse probability weighting) of the likelihood to activate an (1) Internal Gap Funding Program, (2) Internal POC, and (3) Internal USF for the 128 observations of our sample. Model 4 of Panel B presents the Ordered Probit regression of the perceived effectiveness of the subsample of 48 internal gap funding instruments. Each model of Panel B uses three groups of control variables (TTO-, university-, and environment-level characteristics). Marginal effects are provided for Panel a and Models 1-3 of Panel B. Coefficients are provided for Model 4 of Panel B. Standard errors are in parentheses. ${ }^{* * *} p<.01 . * * p<.05 . * p<.1$.

\begin{tabular}{|c|c|}
\hline Panel A & Respondent \\
\hline \multicolumn{2}{|l|}{ University-level characteristics } \\
\hline \multirow[t]{2}{*}{ Northern Europe } & 0.0137 \\
\hline & -0.0625 \\
\hline \multirow[t]{2}{*}{ Southern Europe } & $0.160 * *$ \\
\hline & -0.0745 \\
\hline \multirow{2}{*}{ Western Europe } & -0.0364 \\
\hline & -0.0565 \\
\hline \multirow[t]{2}{*}{ University Research Quality } & $0.317 * * *$ \\
\hline & -0.0668 \\
\hline \multirow[t]{2}{*}{ Constant } & $-0.977 * * *$ \\
\hline & $(0.175)$ \\
\hline Loglikelihood & -288.959 \\
\hline Chi-squared & $38.75 * * *$ \\
\hline Pseudo R-squared & 0.063 \\
\hline Observations & 589 \\
\hline Model & Probit \\
\hline
\end{tabular}

\begin{tabular}{|c|c|c|c|c|}
\hline Panel B & $\begin{array}{c}\text { (1) } \\
\text { Internal Gap } \\
\text { Funding Program }\end{array}$ & $\begin{array}{c}\text { (2) } \\
\text { Internal POC }\end{array}$ & $\begin{array}{c}\text { (3) } \\
\text { Internal USF }\end{array}$ & $\begin{array}{c}(4) \\
\text { Perceived } \\
\text { Effectiveness }\end{array}$ \\
\hline Internal USF & & & & $\begin{array}{l}-0.197 \\
(0.406)\end{array}$ \\
\hline \multicolumn{5}{|l|}{ TTO-level Characteristics } \\
\hline TTO Age & $\begin{array}{l}-0.00253 \\
(0.00805)\end{array}$ & $\begin{array}{l}-0.00435 \\
(0.00750)\end{array}$ & $\begin{array}{l}-0.00222 \\
(0.00416)\end{array}$ & $\begin{array}{c}0.0813^{* *} \\
(0.0395)\end{array}$ \\
\hline Internal TTO & $\begin{array}{r}-0.0714 \\
(0.167)\end{array}$ & $\begin{array}{c}0.127 \\
(0.118)\end{array}$ & $\begin{array}{r}-0.0975 \\
(0.128)\end{array}$ & $\begin{array}{l}0.948^{*} \\
(0.538)\end{array}$ \\
\hline TTO Size & $\begin{array}{l}0.00949 * \\
(0.00578)\end{array}$ & $\begin{array}{l}0.0114 * * \\
(0.00478)\end{array}$ & $\begin{array}{l}0.00467 * \\
(0.00262)\end{array}$ & $\begin{array}{l}-0.0198 \\
(0.0171)\end{array}$ \\
\hline \multicolumn{5}{|l|}{ University-level Characteristics } \\
\hline University Size & $\begin{array}{l}-0.001 \\
(0.001)\end{array}$ & $\begin{array}{l}-0.001 \\
(0.001)\end{array}$ & $\begin{array}{l}-0.001 \\
(0.001)\end{array}$ & $\begin{array}{c}0.001 \\
(0.001)\end{array}$ \\
\hline University Research Quality & $\begin{array}{c}0.106 \\
(0.163)\end{array}$ & $\begin{array}{c}0.220 \\
(0.177)\end{array}$ & $\begin{array}{l}0.243^{*} \\
(0.135)\end{array}$ & $\begin{array}{l}1.078^{*} \\
(0.578)\end{array}$ \\
\hline Technical/Medical University & $\begin{array}{c}-0.0120 \\
(0.161)\end{array}$ & $\begin{array}{l}-0.198 \\
(0.123)\end{array}$ & $\begin{array}{c}0.0845 \\
(0.0931)\end{array}$ & $\begin{array}{c}0.170 \\
(0.499)\end{array}$ \\
\hline Public University & $\begin{array}{l}-0.0235 \\
(0.236)\end{array}$ & $\begin{array}{l}-0.0464 \\
(0.204)\end{array}$ & $\begin{array}{c}0.0806 \\
(0.0596)\end{array}$ & $\begin{array}{c}1.817 \\
(2.096)\end{array}$ \\
\hline University Age & $\begin{array}{c}0.001 \\
(0.001)\end{array}$ & $\begin{array}{c}0.001 \\
(0.001)\end{array}$ & $\begin{array}{l}-0.001 \\
(0.001)\end{array}$ & $\begin{array}{c}0.00174 \\
(0.00166)\end{array}$ \\
\hline \multicolumn{5}{|l|}{ Environment-level Characteristics } \\
\hline Professor Privilege & $\begin{array}{l}-0.241 \\
(0.170)\end{array}$ & $\begin{array}{c}-0.113 \\
(0.168)\end{array}$ & $\begin{array}{l}-0.0336 \\
(0.103)\end{array}$ & $\begin{array}{l}-0.940 \\
(0.922)\end{array}$ \\
\hline Regional GDP & $\begin{array}{c}0.00371 \\
(0.00670)\end{array}$ & $\begin{array}{c}0.00487 \\
(0.00636)\end{array}$ & $\begin{array}{l}-0.00445 \\
(0.00309)\end{array}$ & $\begin{array}{l}0.0545^{*} \\
(0.0298)\end{array}$ \\
\hline Regional Public Funding & $\begin{array}{l}-0.00146^{*} \\
(0.000832)\end{array}$ & $\begin{array}{l}-0.00200 * * \\
(0.000894)\end{array}$ & $\begin{array}{c}0.000697 * * \\
(0.000373)\end{array}$ & $\begin{array}{c}0.00947 * * \\
(0.00478)\end{array}$ \\
\hline Regional High Tech Focus & $\begin{array}{l}0.001 * * \\
(0.001)\end{array}$ & $\begin{array}{l}0.001 * \\
(0.001)\end{array}$ & $\begin{array}{c}0.001 \\
(0.001)\end{array}$ & $\begin{array}{l}-0.0763 \\
(0.0623)\end{array}$ \\
\hline Regional Inventive Activity & $\begin{array}{l}0.000354 \\
(0.00119)\end{array}$ & $\begin{array}{l}0.001000 \\
(0.00113)\end{array}$ & $\begin{array}{c}0.000888 \\
(0.000554)\end{array}$ & $\begin{array}{l}-0.0113 * * \\
(0.00495)\end{array}$ \\
\hline National VC Funding & $\begin{array}{l}7.165^{*} \\
(4.460)\end{array}$ & $\begin{array}{c}4.625 \\
(4.174)\end{array}$ & $\begin{array}{c}0.629 \\
(2.163)\end{array}$ & $\begin{array}{l}33.82 * * \\
(15.35)\end{array}$ \\
\hline Dummv European Area & YES & YES & YES & YES \\
\hline Constant & $\begin{array}{c}-1.381^{*} \\
-0.758\end{array}$ & $\begin{array}{l}-1.502 * \\
(-0.783)\end{array}$ & $\begin{array}{c}-1.923 * * \\
(0.880)\end{array}$ & \\
\hline Observations & 128 & 128 & 128 & 48 \\
\hline Loglikelihood & -285.253 & -252.31 & -205.093 & -43.15 \\
\hline Chi-squared & $36.20 * * *$ & $39.46 * * *$ & $56.80 * * *$ & $30.93 * *$ \\
\hline Pseudo R-squared & 0.294 & 0.358 & 0.298 & 0.264 \\
\hline Model & Probit & Probit & Probit & Ordered Probit \\
\hline
\end{tabular}




\section{Table 7. Comparison of proportion tests}

This table presents comparison of proportions tests between our sample and the population for the purpose of identifying potential sample selection bias. To show that the data are representative of the population, Panel A compares the regional distribution of universities and Panel B compares the research quality of the universities according to the Times Higher Education Ranking.

\begin{tabular}{|c|c|c|c|c|c|c|}
\hline \multirow{2}{*}{$\begin{array}{l}\text { Panel A } \\
\text { University European area }\end{array}$} & \multicolumn{2}{|l|}{ Population } & \multicolumn{2}{|l|}{ Our data } & \multicolumn{2}{|c|}{ Comparison of proportion test } \\
\hline & Total \# of universities & $\begin{array}{l}\text { Proportion of } \\
\text { universities }\end{array}$ & Total \# of universities & $\begin{array}{l}\text { Proportion of } \\
\text { universities }\end{array}$ & Coefficient & Sign \\
\hline Eastern Europe & 589 & 0.12 & 128 & 0.09 & 0.94 & \\
\hline Northern Europe & 589 & 0.25 & 128 & 0.29 & -0.86 & \\
\hline Southern Europe & 589 & 0.19 & 128 & 0.27 & -2.21 & $* *$ \\
\hline Western Europe & 589 & 0.44 & 128 & 0.34 & 1.95 & $* *$ \\
\hline Panel B & Population & & Our data & & Compariso & portion test \\
\hline Top 200 & 589 & 0.10 & 128 & 0.24 & -4.35 & $* * *$ \\
\hline Other & 589 & 0.90 & 128 & 0.76 & 4.35 & $* * *$ \\
\hline
\end{tabular}




\section{Table 8. Distribution of the Perceived Effectiveness variable}

This table presents the distribution of the Perceived Effectiveness variable along the 5 values of the Likert scale for the 48 observations of our sample.

\begin{tabular}{clll}
\hline Perceived Effectiveness & Frequency & Percent & Cumulative \\
\hline 1 & 1 & 2.08 & 2.08 \\
2 & 3 & 6.25 & 8.33 \\
3 & 20 & 41.67 & 50.00 \\
4 & 19 & 39.58 & 89.58 \\
5 & 5 & 10.42 & 100.00 \\
\hline Total & 48 & 100.00 & \\
\hline
\end{tabular}

\section{Table 9. Normality tests for the Perceived Effectiveness variable}

This table presents the Shapiro-Wilk and Shapiro-Francia normality tests. W and W' statistics with p-value greater than 0.05 do not reject the null hypothesis that the variable Perceived Effectiveness is normally distributed.

\begin{tabular}{l|ccc|ccc}
\hline & \multicolumn{3}{|c|}{ Shapiro-Wilk } & \multicolumn{3}{c}{ Shapiro-Francia } \\
\hline & Sample size & $\begin{array}{c}\text { Shapiro-Wilk } \\
\text { (W) statistics }\end{array}$ & p-value & Sample size & $\begin{array}{c}\text { Shapiro-Francia } \\
\text { (W') statistics }\end{array}$ & p-value \\
\hline Perceived effectiveness & 48 & 0.979 & 0.573 & 48 & 0.995 & 0.997 \\
\hline
\end{tabular}


Figure 1. Representation of POC and USF programs

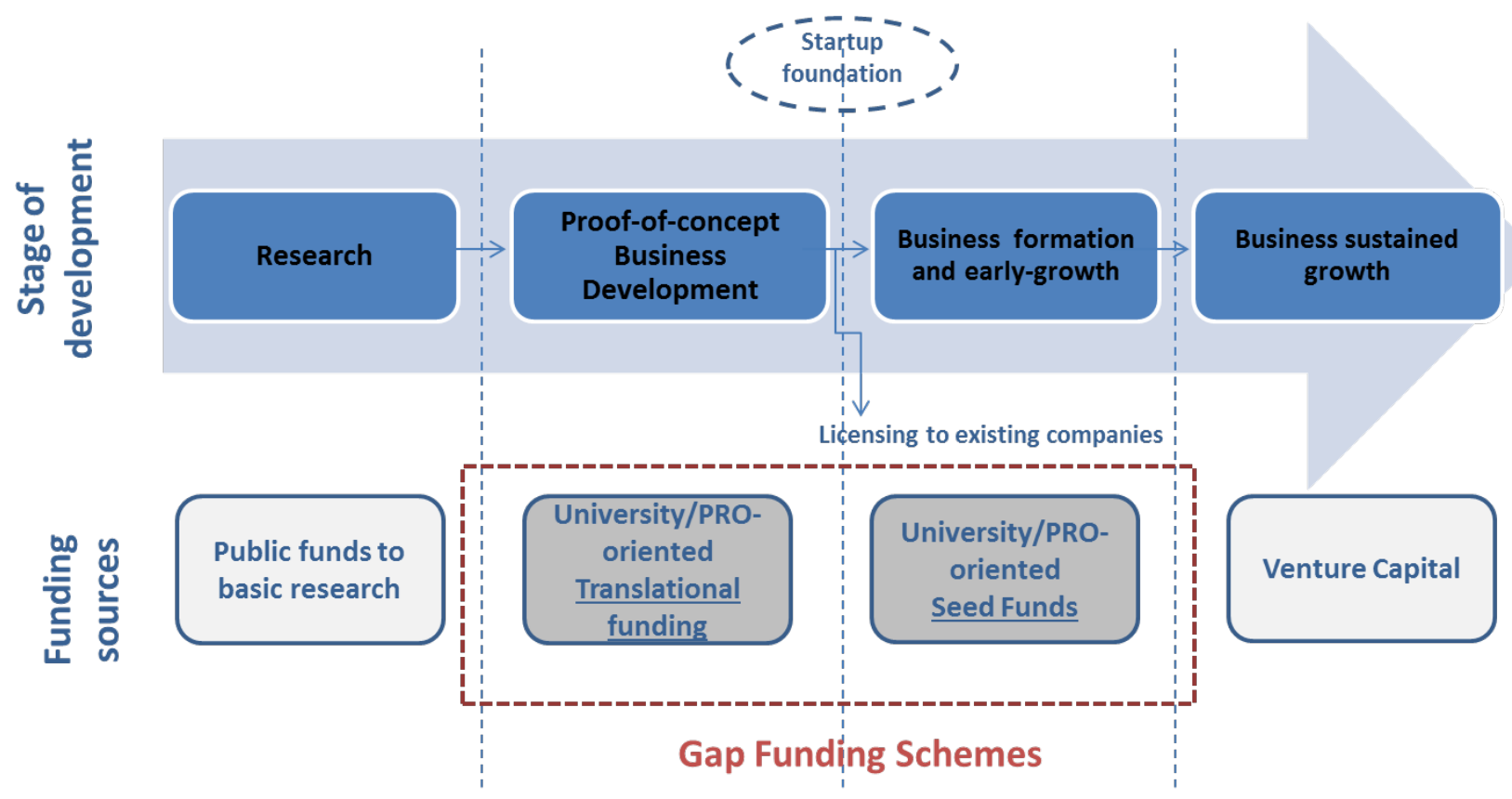

Figure 2. Multilevel framework to assess universities' engagement in gap funding programs

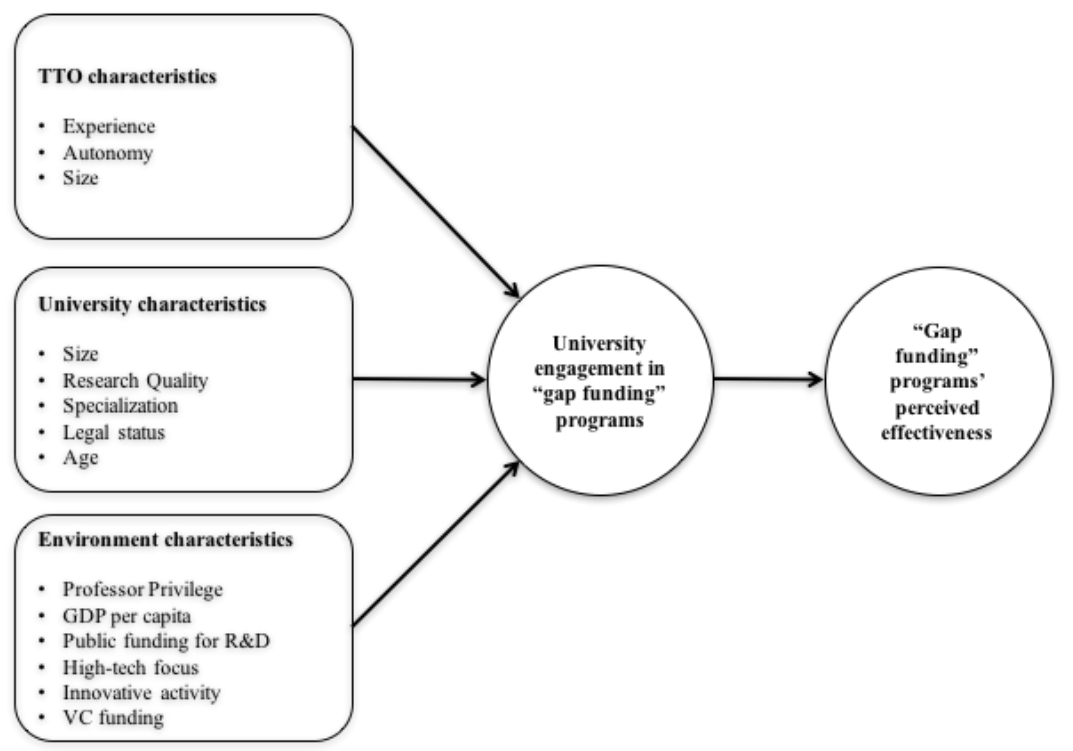

